\title{
Adjudin, a potential male contraceptive, exerts its effects locally in the seminiferous epithelium of mammalian testes
}

\author{
Ka-Wai Mok, Dolores D Mruk, Pearl P Y Lie, Wing-Yee Lui ${ }^{1}$ and C Yan Cheng \\ The Mary M. Wohlford Laboratory for Male Contraceptive Research, Center for Biomedical Research, Population \\ Council, 1230 York Avenue, New York, New York 10065, USA and ${ }^{1}$ School of Biological Sciences, University \\ of Hong Kong, Hong Kong, People's Republic of China
}

Correspondence should be addressed to C Y Cheng; Email: y-cheng@popcbr.rockefeller.edu

\begin{abstract}
Adjudin is a derivative of $1 \mathrm{H}$-indazole-3-carboxylic acid that was shown to have potent anti-spermatogenic activity in rats, rabbits, and dogs. It exerts its effects most notably locally in the apical compartment of the seminiferous epithelium, behind the blood-testis barrier, by disrupting adhesion of germ cells, most notably spermatids to the Sertoli cells, thereby inducing release of immature spermatids from the epithelium that leads to infertility. After adjudin is metabolized, the remaining spermatogonial stem cells and spermatogonia repopulate the seminiferous epithelium gradually via spermatogonial self-renewal and differentiation, to be followed by meiosis and spermiogenesis, and thus fertility rebounds. Recent studies in rats have demonstrated unequivocally that the primary and initial cellular target of adjudin in the testis is the apical ectoplasmic specialization, a testis-specific anchoring junction type restricted to the interface between Sertoli cells and elongating spermatids (from step 8 to 19 spermatids). In this review, we highlight some of the recent advances and obstacles regarding the possible use of adjudin as a male contraceptive.

Reproduction (2011) $\mathbf{1 4 1} 571-580$
\end{abstract}

\section{Introduction}

Population growth in the next four decades, if unchecked, will become one of the major global issues because of limited resources on our planet. In the year 2005, human population in the world has reached about 6.5 billion (Cleland et al. 2006), and it is estimated that in the year 2050, this number will reach $\sim 9$ billion (Cleland et al. 2006). This poses a growing pressure to the limited resources, such as land, water, food, and fossil fuels. Moreover, over population has also threatened the environment via increasing industrial activities. For example, increase in the land use for food production and industrial activities has caused a loss in natural habitats and biodiversity (Cleland et al. 2006), and an increase in the level of toxicants in the environment has threatened the health of the public (Hunt et al. 2009, Siu et al. 2009, Cheng et al. 2011). In order to solve these problems, one of the best solutions is education through family planning and contraception. Indeed, besides preservation of recourses and environment, population control can aid the economic development of underdeveloped and developing countries that have high birth rate by releasing women from domestic activities, contributing to financial stability and security in a family (Eastwood \& Lipton 1999, Chen \& Ravallion 2004). Therefore, there is a strong urge to develop more contraceptives to meet the needs of population control. Today, the burden of contraception rests mostly on women. Although recent surveys have indicated that men in different nations are willing to share the responsibility for contraception (Martin et al. 2000), choices for men are rather limited. Currently available contraception for men includes condom and vasectomy. Although condom has some advantages such as its convenience and cost effectiveness, its efficacy is relatively low and rather unreliable as there is still a $2 \%$ pregnancy rate (Trussell 2004). For vasectomy, this procedure is irreversible and an additional surgical procedure is needed to restore fertility. Also, some unwanted immunological consequences and pathological conditions are associated with vasectomy, at least in some men (Davis \& Pollack 1994). Limited options for male contraception are due to a number of reasons. One of them is the difficulty in suppressing the production of a large number of sperm, which is up to 100 million sperm produced per day by each man from puberty throughout his entire lifespan (Sharpe 1994), without any adverse effects. It is noted that a $90 \%$ suppression of sperm production can still lead to unwanted pregnancy (Robaire 2003). One of the most investigated approaches to block sperm production is hormonal contraception, which disrupts the hypothalamic-pituitary-testicular axis, most notably with the 
use of testosterone by injection, implants, or gels, to suppress GNRH production, thereby reducing intratesticular androgen level to maintain spermatogenesis (Amory et al. 2006, Aitken et al. 2008, Page et al. 2008). Although promising clinical results were obtained from several recently conducted clinical trials, such as a 1.1 contraceptive failure rate per 100 persons (Gu et al. 2008), the development of hormonal contraception still has to overcome certain obstacles. These included the differences in efficacy of spermatogenesis suppression by testosterone from race to race (WHO Task Force on Methods for the Regulation of Male Fertility 1990, Handelsman et al. 1995) and the possible long-term adverse effects resulting from disruption of hypothalamic-pituitary-testicular axis, such as bone loss, prostate enlargement, and elevated blood pressure in men (Holmang et al. 1993, Ducharme 2010, Moulana et al. 2011). Therefore, there is a need for nonhormonal contraception. Immunocontraception may likely be another viable option (McLaughlin \& Aitken 2011). Immunocontraceptive vaccines lead to infertility by raising antibodies against sperm-specific antigens or specific proteins related to sperm production (McLaughlin \& Aitken 2011). A recent study on using a testis/ epididymis-specific protein called epididymis protease inhibitor (eppin) as the target antigen was able to induce infertility in seven out of nine monkeys $\left(\mathrm{O}^{\prime}\right.$ Rand et al. 2004). Despite the success in demonstrating the potential of eppin for the development of immunocontraceptive vaccine by the above-mentioned study, there are still concerns for immunocontraception to be developed as an ideal contraceptive. For example, the two monkeys that did not produce high-titer antibodies against eppin is a concern regarding its efficacy because there are differences in immunological response as a result of genetic variations among individuals in particular in men.

Although the biology of the hypothalamic-pituitarytesticular axis and the intriguing interactions of multiple hormones (e.g. GNRH, FSH, LH, testosterone, and estradiol-17 $\beta$ ) that are crucial to spermatogenesis are known (Sharpe 1994, Winters \& Moore 2007, Carreau et al. 2010), the cell and molecular biology of spermatogenesis, in particular the mechanisms that regulate the local events in the seminiferous epithelium, remains poorly understood. For instance, the cell cycle progression and regulation underlying meiosis remain largely unknown (Lie et al. 2009a, Wolgemuth \& Roberts 2010). The biology and regulation of spermiogenesis, spermiation, and blood-testis barrier (BTB) pertinent to spermatogenesis such as cross talks between different sets of proteins (e.g. protein kinases, phosphatases) and ultrastructure (Cheng \& Mruk 2002, 2010b, Kierszenbaum et al. 2007, Mruk et al. 2008, O'Donnell et al. 2011) are also poorly understood. Nonetheless, recent studies in the field have identified several potential compounds that exert their effects in the seminiferous epithelium, causing exfoliation of germ cells in the testis. One of these compounds is adjudin (Cheng et al. 2005,
Mruk et al. 2008). We also briefly discuss gamendazole and CDB-4022 (Koduri et al. 2008, Tash et al. 2008a), which are also actively investigated as alternatives for non-hormonal contraception. Some recent studies have shown that these compounds exert their effects on the apical ectoplasmic specialization (ES; Cheng \& Mruk 2002, Mruk \& Cheng 2004a, 2004b, Koduri et al. 2008, Tash et al. 2008b) in the seminiferous epithelium. Since apical ES is a testis-specific cell-cell actin-based adhesion ultrastructure (Vogl \& Soucy 1985, Vogl et al. 2000, Cheng \& Mruk 2010b), and if these compounds indeed limit their effects to this ultrastructure, it is expected that these compounds would display high efficacy and low toxicity. In this review, we discuss recent development in the field regarding adjudin, gamendazole, and CDB-4022 and their potentials of becoming male contraceptives.

\section{Adjudin \\ Background}

Adjudin, 1-(2,4-dichlorobenzyl)-1H-indazole-3-carbohydrazide, formerly called AF-2364 (Fig. 1 and Table 1), is an analog of lonidamine (Cheng et al. 2001; Fig. 1). Lonidamine was initially explored as an anti-cancer drug without anti-mitotic activity, unlike most other anti-cancer drugs (Silvestrini et al. 1984). Interestingly, lonidamine was later found to be an effective anti-spermatogenic agent (Coulston et al. 1975, Corsi \& Palazzo 1976, Lobl 1979, Lobl et al. 1979 ) that could induce vacuolation of endoplasmic

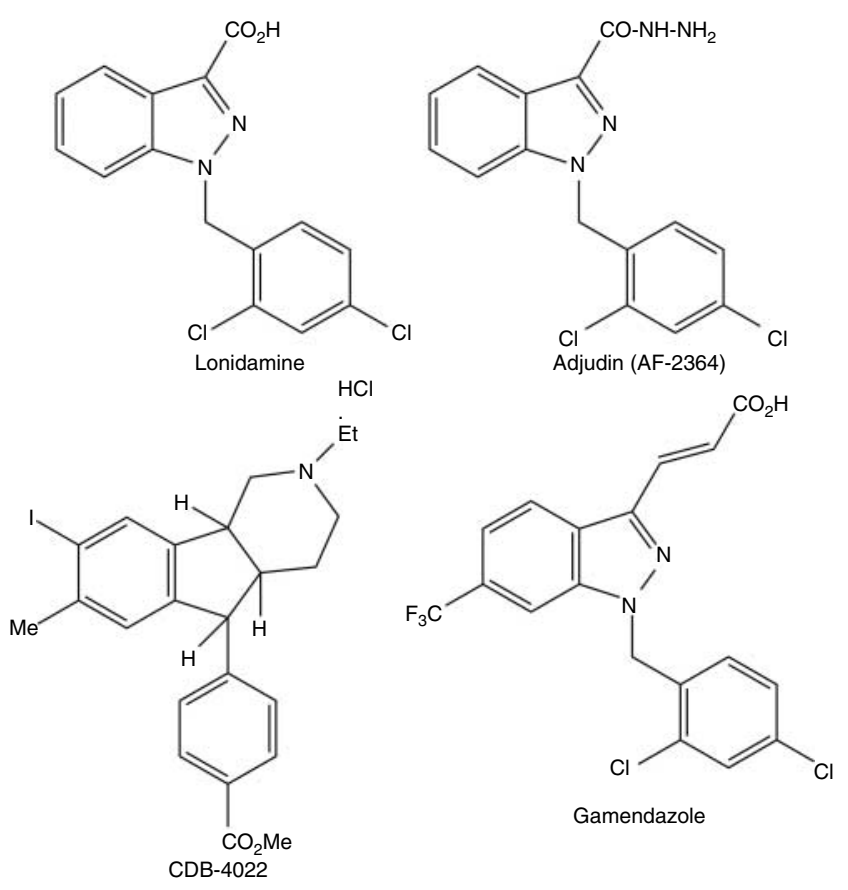

Figure 1 Structural formulae of lonidamine, adjudin, gamendazole, and CDB-4022. 
Table 1 A summary of the efficacy, toxicity, and sites of action for adjudin versus gamendazole and CDB-4022.

\begin{tabular}{|c|c|c|c|}
\hline & \multicolumn{3}{|c|}{ Compound } \\
\hline & Adjudin & Gamendazole & CDB-4022 \\
\hline $\begin{array}{l}\text { Min. effective dosage for } \\
100 \% \text { efficacy }\end{array}$ & $\begin{array}{l}\text { Two doses of } 50 \mathrm{mg} / \mathrm{kg} \text { b.w. } \\
\quad \text { (one dose per week) }\end{array}$ & Single dose of $6 \mathrm{mg} / \mathrm{kg}$ b.w. & $\begin{array}{l}\text { Single dose of } 2 \mathrm{mg} / \mathrm{kg} \text { b.w. for rats } \\
\text { Seven daily doses of } 12.5 \mathrm{mg} / \mathrm{kg} \\
\text { b.w. for monkeys }\end{array}$ \\
\hline $\begin{array}{l}\text { Reversibility at min. } \\
\text { effective dosage }\end{array}$ & $100 \%$ & $57 \%$ & $\begin{array}{l}0 \% \text { in rats } \\
100 \% \text { in monkeys }\end{array}$ \\
\hline $\begin{array}{l}\text { Level of FSH, } \mathrm{LH} \text {, and } \\
\quad \text { testosterone after treatment }\end{array}$ & $\begin{array}{l}\mathrm{FSH}(-), \mathrm{LH}(-), \text { and } \\
\quad \text { testosterone }(-)\end{array}$ & $\begin{array}{l}\mathrm{FSH}(\mathrm{NS} \uparrow) \text {, and } \\
\quad \text { testosterone }(-)\end{array}$ & $\begin{array}{l}\mathrm{FSH}(\uparrow), \mathrm{LH}(-), \text { and } \\
\quad \text { testosterone }(-)\end{array}$ \\
\hline Lethal dosage & $\begin{array}{l}\text { No toxic effects for single dose up } \\
\text { to } 2000 \mathrm{mg} / \mathrm{kg} \text { b.w. and no } \\
\text { fatality at } 50 \mathrm{mg} / \mathrm{kg} \text { b.w. per day } \\
\text { for } 29 \text { days for } 10 \text { male and } \\
10 \text { female rats (subchronic } \\
\text { toxicity test) }\end{array}$ & $200 \mathrm{mg} / \mathrm{kg}$ b.w. & Not determined \\
\hline Sites of action & $\begin{array}{l}\text { Activation of integrin/FAK/ERK } \\
\text { signaling pathway } \\
\text { Activation of integrin/RhoB/cofilin } \\
\text { signaling pathway } \\
\text { Down-regulation of EPS8 } \\
\text { Causing truncated localization } \\
\text { of ARP3 }\end{array}$ & $\begin{array}{l}\text { Partial inhibition of eEF1A1 } \\
\text { Partial inhibition of HSP90 }\end{array}$ & $\begin{array}{l}\text { Alteration of expression of } \\
\text { apical ES proteins } \\
\text { Activation of ERK-MAPK signaling } \\
\text { pathway } \\
\text { Decreasing the ratio of membrane } \\
\text { to soluble form SCF } \\
\text { Activation of pro-apoptotic factors }\end{array}$ \\
\hline Effect(s) & $\begin{array}{l}\text { Premature spermiation due to } \\
\text { disruption of apical ES }\end{array}$ & $\begin{array}{l}\text { Premature spermiation due to } \\
\text { disruption of apical ES }\end{array}$ & $\begin{array}{l}\text { Premature spermiation due to } \\
\quad \text { disruption of apical ES } \\
\text { An increase in germ cell apoptosis }\end{array}$ \\
\hline References & $\begin{array}{l}\text { Cheng et al. (2001, 2005), Grima } \\
\text { et al. (2001), Lie et al. (2009b, } \\
\text { 2010), Lui et al. (2003), Siu et al. } \\
\text { (2003) and Mruk et al. (2006) }\end{array}$ & Tash et al. (2008a, 2008b) & $\begin{array}{l}\text { Hild et al. }(2001,2007) \text { and } \\
\quad \text { Koduri et al. }(2008)\end{array}$ \\
\hline
\end{tabular}

$\uparrow$, Stimulation; - , no change; min, minimal; NS, not significantly; SCF, stem cell factor.

reticulum of Sertoli cells and exfoliation of germ cells from the seminiferous epithelium (Buthala \& Lobl 1979, Lobl 1979, Lobl et al. 1979, De Martino et al. 1981) in mammalian testes. However, it has a number of side effects including muscular pain, testicular pain, vomiting, and elevation of liver enzymes as a sign of liver damage (Silvestrini et al. 1984). Besides, its margin between its efficacy dose and toxicity is very narrow (Heywood et al. 1981, Silvestrini et al. 1984, Robustelli della Guna \& Pedrazzoli 1991). Thus, there are some efforts among investigators to develop derivatives of lonidamine for the purpose of maintaining its antispermatogenic effect and at the same time minimizing its toxicity, and adjudin and gamendazole are the results of such efforts.

\section{Efficacy and toxicity of adjudin}

Adjudin (Fig. 1 and Table 1) was identified almost a decade ago in our laboratory as a potential male contraceptive (Cheng et al. 2001) following the screening of more than two dozen derivatives of lonidamine based on a novel assay involving testin, an apical ES signaling protein, to identify an analog that is highly specific to perturb apical ES function with minimal cytotoxicity (Cheng et al. 2001). Results showed that two doses of $50 \mathrm{mg} / \mathrm{kg}$ b.w. of adjudin (one dose per week) could induce $100 \%$ infertility by $\sim 5$ weeks following treatment in adult rats and their fertility rebounded by $\sim 11$ weeks to $100 \%$ (Cheng et al. 2001, 2005). Adjudin was effective to induce complete reversible infertility in adult rats (Cheng et al. 2001), rabbits (Hu et al. 2009), and dogs (Zhou et al. 2008) without fatality, and had no apparent side effects in treated male animals based on serum microchemistry to monitor the liver and kidney function. The lack of general toxicity of adjudin was also reflected by no reduction of body weight after treatment in these animals. Moreover, histological analyses had shown that cell adhesion in other organs, such as kidney, liver, brain, heart, epididymis, prostate, and seminal vesicles, was not affected in rat treated with adjudin (Grima et al. 2001). Furthermore, toxicity studies conducted by licensed toxicologists confirmed that adjudin has no genotoxicity and is not toxic in acute dose even at $2000 \mathrm{mg} / \mathrm{kg}$ b.w. in rats and mice (Mruk et al. 2006). More remarkably, the serum testosterone, FSH, and $\mathrm{LH}$ levels of the adjudin-treated animals had no detectable change compared with the control animals (Cheng et al. 2001, Grima et al. 2001). 
Thus, the hypothalamic-pituitary-testicular axis is not disrupted. Although adjudin appears to be safe as a male contraceptive based on a series of tests performed by licensed toxicologists including acute toxicity, genotoxicity, and mutagenesis (see Supplementary Data in Mruk et al. (2006)), the margin between its efficacy and toxicity was too narrow. Based on a 29-day subchronic toxicity study in ten male and ten female rats, it was shown that three out of the ten male rats, but none in the female rats, displayed signs of liver inflammation and skeletal muscle atrophy (Mruk et al. 2006). Therefore, we had developed a conjugate to deliver adjudin specifically to the testis using an FSH mutant to significantly reduce the efficacy dosing and thereby lowering the systemic toxicity (Mruk et al. 2006), by making use of the fact that FSH receptor is limited to the Sertoli cell in the mammalian body (Sprengel et al. 1990, Griswold et al. 1995). Although effective dose was lowered to $50 \mu \mathrm{g} / \mathrm{kg}$ b.w., this approach was proven to be prohibitively expensive for a male contraceptive because of the production costs (Mruk \& Cheng 2008). We have made some advances in preparing different formulations of adjudin for its oral use in laboratory studies, and our goal is to reduce the effective dosing of adjudin to $\sim 5-7.5 \mathrm{mg} \mathrm{kg} / \mathrm{b} . \mathrm{w}$. from the current $50 \mathrm{mg} / \mathrm{kg}$ b.w. (for a review, see Wong et al. $(2008 b))$, with some success based on ongoing studies in our laboratory.

\section{Cellular targets of adjudin in the testis}

The primary ultrastructural target of adjudin appears to be the apical ES. This conclusion is based on the following observations from recent published reports. First, it is known that apical ES is a unique actin-based adhesive ultrastructure in the testis. Apical ES is restricted to the interface between Sertoli cells and step 8-19 spermatids in the rat testis, which is typified by the presence of bundles of actin filament bundles sandwiched in between the cisternae of endoplasmic reticulum and the apposing plasma membranes of the Sertoli cell and the elongating spermatid. This ultrastructural feature, however, is visible only on the Sertoli cell side in the seminiferous epithelium by electron microscopy (Cheng \& Mruk 2009, 2010b; Fig. 2). Once it appears, it is the only anchoring device that anchors developing spermatids to the Sertoli cell during spermiogenesis, replacing desmosomes and gap junctions (Russell 1993, Cheng \& Mruk 2010b). Studies by using micropipette pressure transducing system (MPTS) to quantify the physical force that is required to pull i) spermatocytes, ii) pre-step 8 spermatids, and iii) step 8-19 spermatids away from the Sertoli cell epithelium have demonstrated that apical ES is the strongest adhesive ultrastructure versus desmosomes and gap junctions (Wolski et al. 2005). In this context, it is noted that apical ES is present only in step 8-19 spermatids, but not in spermatocytes and pre-step 8 spermatids because desmosome and gap junction are restricted to the interface between Sertoli cells and spermatocytes or early developing spermatids (pre-step 8 spermatids; Cheng \& Mruk 2010b, Lie et al. 2011). Yet, adjudin is more effective to disrupt the adhesive force that maintains the apical ES versus desmosomes and gap junctions found between spermatocytes/round spermatids and Sertoli cells as assessed by MPTS (Wolski et al. 2006), implying that apical ES is one of the primary targets of adjudin in the seminiferous epithelium. These findings are important and they are also consistent with an earlier in vivo study to assess the kinetics of germ cell loss from the epithelium in adjudintreated rats. It was reported that the halftime for the loss of elongating spermatids (i.e. the time it took for step 8-19 spermatids to be found in the tubule lumen in $50 \%$ of the seminiferous tubules examined based on morphometric/histological analysis) was only $6.5 \mathrm{~h}$; in contrast, the halftime of round spermatid and spermatocyte depletion was 3 and 6 days respectively (Chen et al. 2003). Thus, this earlier in vivo study has shown that adjudin is significantly more effective in inducing the loss of elongating spermatids (i.e. step 8-19 spermatids) from the epithelium than the round spermatids and spermatocytes (Chen et al. 2003), consistent with the subsequent in vitro studies to quantify the 'force' required to disrupt adhesion between Sertoli cells versus spermatocytes, round spermatids (pre-step 8 spermatids), and step 8-19 spermatids (Wolski et al. 2006).

Secondly, adjudin was shown to induce the expression of several integral membrane proteins at the apical ES in the testis, such as $\beta 1$-integrin (Siu et al. 2003) and $\mathrm{N}$-cadherin (Lee et al. 2003), and to activate the downstream signaling pathways that eventually perturb cell adhesion at the apical ES in the testis. One of these pathways is the integrin/FAK (focal adhesion kinase)/ phosphatidylinositol 3-kinase (PI-3 kinase)/p130Cas/ MAP kinase signaling pathway (Siu et al. 2003; Fig. 2), which is known to regulate the apical ES by affecting the underlying actin-based cytoskeleton network (Lee \& Cheng 2004b). Thus, the effects of adjudin on the $\beta 1$-integrin-based adhesion protein complex at the apical ES may account for the preferential disruption of adhesion between elongating spermatids and Sertoli cells (Chen et al. 2003, Wolski et al. 2006; see above). Since $\beta 1$-integrin is found in virtually all epithelia/ endothelia but at the cell-matrix interface, one will argue that if adjudin indeed exerts its effects on $\beta 1$-integrin and its downstream signaling pathway at the apical ES, the adhesion function in multiple epithelia would have been affected systemically. However, in both acute and subchronic toxicity studies performed by licensed toxicologists and pathologists, it was shown that adjudin did not affect cell adhesion function in multiple tissues and organs (Grima et al. 2001) based on pathological and histological analysis (see 


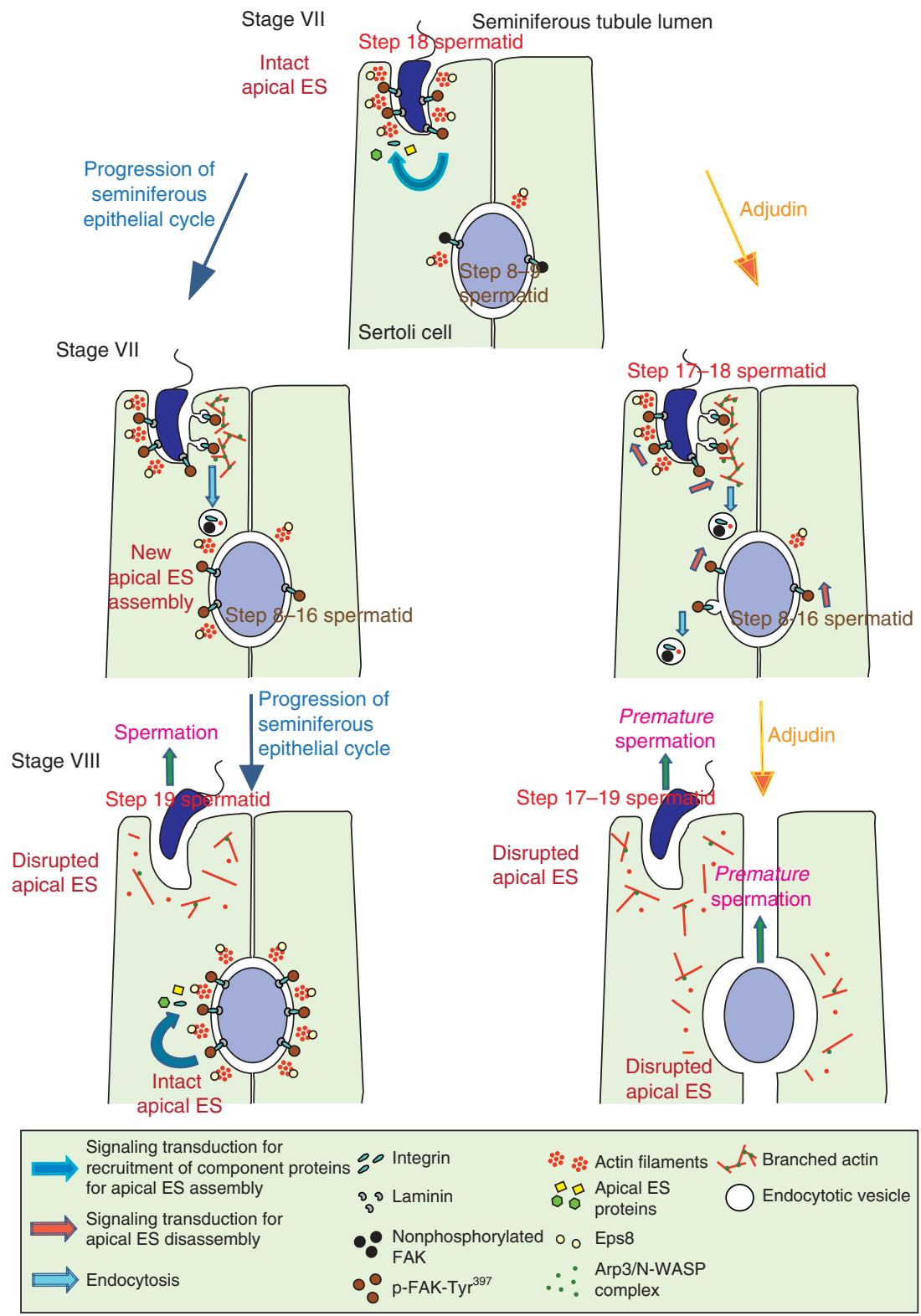

Figure 2 A schematic illustration of the current concepts of mechanism by which adjudin perturbs apical ES function in the seminiferous epithelium to induce germ cell loss from the seminiferous epithelium. During spermatogenesis, such as in the seminiferous epithelium of a stage VII tubule (left panel), the expression of EPS8 is high at the apical ES for the maintenance of F-actin organization via its actin bundling activity to stabilize that apical ES. The integrity of the apical ES in this stage VII tubule is also maintained via an elevated expression of p-FAK-Tyr ${ }^{397}$, perhaps being used to maintain the proper phosphorylation status of the constituent proteins at the apical ES (Siu et al. 2003), as well as to recruit additional adaptors (e.g. p130 Cas, vinculin) to the site to reinforce cell adhesion (Siu \& Cheng 2008). As spermatogenesis proceeds (lower panel), ARP3, whose expression is also high at the apical ES in stage VII (Lie et al. 2010), causes 'debundling' of actin filaments by promoting actin branching. At the same time, endocytosis facilitates recycling of apical ES proteins for the assembly of 'new' apical ES that arises via spermiogenesis such as newly formed step 8 spermatids (Cheng \& Mruk 2010b). At stage VIII of the seminiferous epithelial cycle when spermiation occurs, the apical ES is destabilized as the result of 'debundling' of actin filament due to the down-regulation of EPS8 with concomitant actin branching promoted by ARP3 (Lie et al. $2009 \mathrm{~b}, 2010$ ). On the other hand, new apical ES is being assembled for developing step 8-9 spermatids, such as via protein transcytosis and/or de novo synthesis of 'new' apical ES proteins. When rats are treated with adjudin (right panel), the above-described events, which only take place for step 18-19 spermatids during stage VII-VIII tubule, are 'triggered' to occur 'prematurely' at the apical ES in other stages of tubules with step 8-19 spermatids. Therefore, spermiation takes place 'prematurely' in developing spermatids in other staged tubules besides stage VIII. In addition, p-FAK-Tyr ${ }^{397}$ is highly expressed at the apical ES for the induction of the integrin/FAK/PI3-kinase/p130Cas/MAP kinase signaling pathway (Siu et al. 2003) to further destabilize apical ES to cause 'premature' spermiation in spermatids from steps 8 to 19. 
Supplementary Data in Mruk et al. (2006)) except the seminiferous epithelium in the testis. Interestingly, it is noted that $\beta 1$-integrin is restricted to focal adhesion complex (or focal contact) at the cell-matrix interface in multiple epithelia; however, $\beta 1$-integrin is an integrated component of the cell-cell actin-based anchoring junction apical ES. Apical ES is a hybrid anchoring junction type composed of the physicochemical features of adherens junction, tight junction, desmosome junction, and gap junction (Mruk \& Cheng 2004a, Mruk et al. 2008, Wong et al. 2008a). Furthermore, the ultrastructural features of apical ES are unique, distinguishable from all other anchoring junction types found in mammalian tissues and organs (Mruk \& Cheng 2004a, Yan et al. 2007, Vogl et al. 2008, Cheng \& Mruk $2010 b)$. As such, it is likely that the unique architectural/ molecular features of apical ES have rendered this anchoring junction type in the seminiferous epithelium to be the prime (or more susceptible) target of adjudin.

Thirdly, recent studies have shown that adjudin affects two actin regulatory proteins: i) epidermal growth factor receptor pathway substrate 8 (EPS8) and ii) actin-related protein 3 (ARP3), at the apical ES in the rat testes with some unexpected ramifications. These two proteins were shown to play a role in mediating the apical ES restructuring to facilitate the rapid morphological changes in developing elongating spermatids during spermiogenesis by their highly restricted temporal and spatial expression in the seminiferous epithelium at the ES during the seminiferous epithelial cycle (Lie et al. 2009b, 2010). It was noted that EPS8, an actin bundling protein (Higgs 2004, Hertzog et al. 2010), was normally down-regulated at the apical ES at stage VIII tubules to facilitate the 'debundling' of the actin filament network, thereby destabilizing apical ES to prepare step 19 spermatids to undergo spermiation. However, upon adjudin treatment, EPS8 was found to be downregulated at the apical ES to facilitate actin filament 'debundling' in all tubules instead of restricted to stage VIII tubules (Lie et al. 2009b; Fig. 2). In short, EPS8 is used to maintain the apical ES integrity by stabilizing the F-actin filament organization via its ability of actin bundling in the epithelium during the normal seminiferous epithelial cycle of spermatogenesis. Thus, downregulation of EPS8 by adjudin causes disorganization of F-actin, which leads to disruption of apical ES analogous to inducing 'spermiation' in immature elongating spermatids (Lie et al. 2009b). On the other hand, ARP3 (actin-related protein 3) is part of a functional complex containing ARP2, ARP3, ARPC1-5 (ARP2/3 complex subunit 1 to 5), and WASP (Wiskott-Aldrich syndrome protein) to regulate actin nucleation/branching (Goley \& Welch 2006, Cheng \& Mruk 2011, Campellone \& Welch 2010). The expression of ARP3 was found to be abundant at the apical ES in stage VII tubules to promote actin branching, thereby 'destabilizing' the apical ES to prepare for spermiation that occurs in stage VIII (Lie et al. 2010; Fig. 2). However, treatment of rats with adjudin induced truncated localization of ARP3 (Lie et al. 2010), which is likely being used to disrupt the highly organized actin branching and bundling activity induced by ARP3 and EPS8 respectively, thereby leading premature 'spermiation' on all elongating spermatids (Fig. 2).

Taken collectively, these recent findings have demonstrated unequivocally that one of the primary targets of adjudin is the apical ES, wherein adjudin exerts its effects to induce 'premature spermiation' in step 8-19 spermatids by perturbing the highly restricted temporal and spatial expression of ARP3 and EPS8 (see Fig. 2), leading to transient infertility because of the loss of functional mature sperm in semen.

\section{Gamendazole and CDB-4022}

In this context, it is of interest to note that besides adjudin, two other compounds, namely gamendazole and CDB-4022, appear to exert their effects, at least in part, in the seminiferous epithelium to disrupt germ cell adhesion to induce infertility in rodents. These findings are summarized in this review and briefly discussed in light of the data based on adjudin.

\section{Gamendazole}

Gamendazole (see Fig. 1 and Table 1) is another analog of lonidamine. Recent studies have shown that in rats, a single dose of gamendazole at 3 and $6 \mathrm{mg} / \mathrm{kg}$ b.w. was able to induce 67 and $100 \%$ infertility $\sim 4$-week posttreatment respectively. Fertility of the $3 \mathrm{mg} / \mathrm{kg}$ b.w. treated group rebounded to $100 \%$, whereas only $57 \%$ was achieved in the $6 \mathrm{mg} / \mathrm{kg}$ b.w. treated group (Tash et al. 2008a). Besides being effective in inducing transient infertility, gamendazole appeared to have no side effects to the animals at the dose that was effective to block fertility. There was no loss in body weight of rats treated with gamendazole indicating that this lonidamine derivative had no general toxicity at that dosage. Although mortality was resulted in three out of five animals at the dosage $200 \mathrm{mg} / \mathrm{kg}$ b.w., no observable abnormality including inflammation, necrosis, hemorrhage, or tumor could be detected at dosage lower than $200 \mathrm{mg} / \mathrm{kg}$ b.w. (Tash et al. 2008a). Moreover, the circulating testosterone levels for gamendazole-treated animals had no significant difference from control animals, whereas the FSH levels of the treated animals had only a transient but insignificant increase (Tash et al. 2008a). This indicates that the hypothalamic-pituitarytesticular axis is not disrupted. The fatality that was reported for gamendazole, but not for adjudin that served as a comparative control in the same study (Tash et al. 2008a), is likely due to the presence of the trifluoro group in the indazole ring (see Fig. 1), which was 
observed even a single fluoro group was present (Cheng et al. 2001), and this issue of toxicity has recently been discussed (Cheng \& Mruk 2010a).

As both gamendazole and adjudin are analogs of lonidamine (see Fig. 1), it is not surprising to see that both compounds induce similar phenotypic changes in the seminiferous epithelium of rat testes by depleting germ cells from the tubules (Cheng et al. 2001, 2005, Tash et al. $2008 a, 2008 b)$. Interestingly, gamendazole was shown to exert its action by selectively inhibiting part of the functions of eukaryotic elongation translation factor 1 (eEF1A1; Tash et al. 2008b). eEF1A1 was first identified for its role in protein synthesis as an elongating factor during transcription (Carvalho et al. 1984). It was later found to interact with actin cytoskeleton (Yang et al. 1990 ) and this function is conserved from yeast (Munshi et al. 2001) to human (Liu et al. 2002). Thus, partial inhibition of eEF1A1 might lead to disruption of the eEF1A1-mediated bundling of F-actin and therefore impairing the actin filament bundles necessary to maintain the integrity of the apical ES (Tash et al. 2008b). It was also proposed that gamendazole could induce a temporary reduction in functions of a heatshock protein HSP90, leading to degradation of its client protein AKT1 (Tash et al. 2008b). As AKT1 (also known as $\mathrm{PKB}$, protein kinase $\mathrm{B}$ ) was shown to be involved in maintaining the adhesion between Sertoli cells and spermatids (Siu et al. 2005), a loss of AKT1 thus destabilizes germ cell adhesion, thereby inducing germ cell loss from the epithelium (Tash et al. 2008b). It remains to be determined in future studies if the action of eEF1A1 downstream would involve changes in the restricted expression and/or activation of EPS8 and ARP3 (Lie et al. 2009b, 2010) that leads to an alteration of the actin cytoskeleton as discussed above.

\section{CDB-4022}

CDB-4022, [4aRS,5SR,9bRS]-2-ethyl-2,3,4,4a, 5,9bhexahydro-8-iodo-7-methyl-5-[carbo-methoxy-phenyl]$1 \mathrm{H}$-indeno-[1,2-c]-pyridine-hydrochloride (Fig. 1 and Table 1), is an indenopyridine that was shown to have anti-spermatogenic effects in rodents and monkeys (Hild et al. 2001, 2007). A single dose of CDB-4022 at $2.5 \mathrm{mg} / \mathrm{kg}$ b.w. or seven daily doses of CDB-4022 at $12.5 \mathrm{mg} / \mathrm{kg}$ b.w. was able to induce $100 \%$ infertility in rats (Hild et al. 2001) or monkeys respectively (Hild et al. 2007). Interestingly, the irreversible fertility was different from species to species because CDB-4022 induced irreversible infertility in rats (Hild et al. 2001), but monkeys treated with CDB-4022 could have their fertility rebounded by 16-week post-treatment (Hild et al. 2007). Furthermore, no observable adverse effects such as loss in body weight were found in the treated animals, indicating that this compound had no general toxicity (Hild et al. 2001). One of the sites of action of CDB-4022 was the adherens junction between Sertoli and germ cells. A previous study showed that after CDB-4022 treatment, germ cell adhesion was perturbed due to a loss of nectin-3 and its partner afadin (Koduri et al. 2008) because the nectin-3/afadin adhesion complex is crucial to confer spermatid adhesion at the apical ES (Ozaki-Kuroda et al. 2002). In addition, an activation of ERK-MAPK signaling pathway was also detected (Koduri et al. 2008) during CDB-4022-induced germ cell loss from the epithelium, analogous to the adjudin-induced germ cell loss from the testis (Lee \& Cheng 2004a, Xia et al. 2005, Li et al. 2009).

\section{Concluding remarks and future perspectives}

As briefly discussed in this review, adjudin and two other potential male contraceptives under investigation, namely CDB-4022 and gamendazole, share some similar action in the testis by disrupting germ cell anchoring junctions in the seminiferous epithelium, perhaps mediated by similar molecular mechanism(s), to induce germ cell loss from the testis. However, results of acute and subchronic toxicity for gamendazole are not known. It appears that the next phase of study will likely focus on the preparation of better formulations in order to widen the margin between efficacy and safety so that these compounds, or their second-generation analogs, can move forward in the development pipeline. Although this is a tedious process and can sometimes be frustrating, new and some unexpected findings will be obtained. For instance, the use of adjudin-treated rats becomes a novel in vivo model to study the biology and regulation of different anchoring junctions, including the apical ES and the basal ES, as well the BTB.

\section{Declaration of interest}

The authors declare that there is no conflict of interest that could be perceived as prejudicing the impartiality of this review.

\section{Funding}

Studies in the authors' laboratory were supported by grants from the National Institutes of Health (National Institute of Child Health and Human Development, R01 HD056034 and R01 HD056034-02S1 to C Y Cheng; U54 HD029990 Project 5 to C Y Cheng; and R03 HD061401 to D D Mruk). W-Y Lui was supported by Hong Kong Research Grants Council (HKU771507 and HKU772009).

\section{References}

Aitken RJ, Baker MA, Doncel GF, Matzuk MM, Mauck CK \& Harper MJ 2008 As the world grows: contraception in the 21st century. Journal of Clinical Investigation 118 1330-1343. (doi:10.1172/JCI33873) 
Amory JK, Page ST \& Bremner WJ 2006 Drug insight: recent advances in male hormonal contraception. Nature Clinical Practice. Endocrinology \& Metabolism 2 32-41. (doi:10.1038/ncpendmet0069)

Buthala DA \& Lobl TJ 1979 Electron microscope study of 1-(2,4dichlorobenzyl)-1H-indazole-3-carboxylic acid, an exfoliative antispermatogenic agent, in the rat testis. Cytobios 25 23-28.

Campellone KG \& Welch MD 2010 A nucleator arms race: cellular control of actin assembly. Nature Reviews. Molecular Cell Biology 11 237-251. (doi:10.1038/nrm2867)

Carreau S, Wolczynski S \& Galeraud-Denis I 2010 Aromatase, estrogens and human male reproduction. Philosophical Transactions of the Royal Society of London. Series B. Biological Sciences 365 1571-1579. (doi:10.1098/rstb.2009.0113)

Carvalho MD, Carvalho JF \& Merrick WC 1984 Biological characterization of various forms of elongation factor 1 from rabbit reticulocytes. Archives of Biochemistry and Biophysics 234 603-611. (doi:10.1016/00039861(84)90310-2)

Chen S \& Ravallion M 2004 How have the world's poorest fared since the early 1980s? World Bank Research Observer 19 141-169. (doi:10.1093/ wbro/lkh020)

Chen YM, Lee NPY, Mruk DD, Lee WM \& Cheng CY 2003 Fer kinase/Fer T and adherens junction dynamics in the testis: an in vitro and in vivo study. Biology of Reproduction 69 656-672. (doi:10.1095/biolreprod. 103.016881)

Cheng CY \& Mruk DD 2002 Cell junction dynamics in the testis: Sertoli-germ cell interactions and male contraceptive development. Physiological Reviews 82 825-874. (doi:10.1152/physrev.00009.2002)

Cheng CY \& Mruk DD 2009 An intracellular trafficking pathway in the seminiferous epithelium regulating spermatogenesis: a biochemical and molecular perspective. Critical Reviews in Biochemistry and Molecular Biology 44 245-263. (doi:10.1080/10409230903061207)

Cheng CY \& Mruk DD 2010a The biology of spermatogenesis: the past, present and future. Philosophical Transactions of the Royal Society of London. Series B. Biological Sciences 365 1459-1463. (doi:10.1098/ rstb.2010.0024)

Cheng CY \& Mruk DD 2010b A local autocrine axis in the testes that regulates spermatogenesis. Nature Reviews. Endocrinology 6 380-395. (doi:10.1038/nrendo.2010.71)

Cheng CY \& Mruk DD 2011 Regulation of spermiogenesis, spermiation and blood-testis barrier dynamics: novel insights from sudies on Eps8 and Arp3. Biochemical Journal [in press]. (doi:10.1042/BJ20102121)

Cheng CY, Silvestrini B, Grima J, Mo MY, Zhu LJ, Johansson E, Saso L, Leone MG, Palmery M \& Mruk DD 2001 Two new male contraceptives expert their effects by depleting germ cells prematurely from the testis. Biology of Reproduction 65 449-461. (doi:10.1095/biolreprod65.2.449)

Cheng CY, Mruk DD, Silvestrini B, Bonanomi M, Wong $\mathbf{C H}$, Siu MK, Lee NP, Lui WY \& Mo MY 2005 AF-2364 [1-(2,4-dichlorobenzyl)-1Hindazole-3-carbohydrazide] is a potential male contraceptive: a review of recent data. Contraception 72 251-261. (doi:10.1016/j.contraception. 2005.03.008)

Cheng CY, Wong EWP, Lie PPY, Li MWM, Su L, Siu ER, Yan HHN, Mannu J, Mathur PP, Bonanomi M et al. 2011 Environmental toxicants and male reproductive function. Spermatogenesis 1 2-13. (doi:10.4161/spmg.1.1. 13971)

Cleland J, Bernstein S, Ezeh A, Faundes A, Glasier A \& Innis J 2006 Family planning: the unfinished agenda. Lancet 368 1810-1827. (doi:10.1016/ S0140-6736(06)69480-4)

Corsi G \& Palazzo G 1976 1-Halobenzyl-1H-indazole-3-carboxylic acids. A new class of antispermatogenic agents. Journal of Medicinal Chemistry 19 779-783. (doi:10.1021/jm00228a008)

Coulston F, Dougherty W, LeFevre R, Abraham R \& Silvestrini B 1975 Reversible inhibition of spermatogenesis in rats and monkeys with a new class of indazol-carboxylic acids. Experimental and Molecular Pathology 23 357-366. (doi:10.1016/0014-4800(75)90029-5)

Davis J \& Pollack AE 1994 Vasectomy. In Fertility Control, 2nd edn, pp 319-338. Eds SL Corson, RJ Deman \& LB Tyrer. London: Golden Publisher.

De Martino C, Malcorni W, Bellocci M, Floridi A \& Marcante ML 1981 Effects of AF 1312 TS and lonidamine on mammalian testis. A morphological study. Chemotherapy 27 27-42. (doi:10.1159/000238043)

Ducharme N 2010 Male osteoporosis. Clinics in Geriatric Medicine 26 301-309. (doi:10.1016/j.cger.2010.02.005)
Eastwood R \& Lipton M 1999 The impact of changes in human fertility on poverty. Journal of Development Studies 36 1-30. (doi:10.1080/ 00220389908422609)

Goley ED \& Welch MD 2006 The ARP2/3 complex: an actin nucleator comes of age. Nature Reviews. Molecular Cell Biology 7 713-726. (doi:10.1038/nrm2026)

Grima J, Silvestrini B \& Cheng CY 2001 Reversible inhibition of spermatogenesis in rats using a new male contraceptive, 1-(2,4 -dichlorobenzyl)-indazole-3-carbohydrazide. Biology of Reproduction 64 1500-1508. (doi:10.1095/biolreprod64.5.1500)

Griswold MD, Heckert L \& Linder C 1995 The molecular biology of the FSH receptor. Journal of Steroid Biochemistry and Molecular Biology 53 215-218. (doi:10.1016/0960-0760(95)00049-6)

Gu YQ, Liang XW, Wu WX, Liu ML, Song SX, Cheng LF, Bo LW, Xiong CL, Wang XH, Liu XZ et al. 2008 Multicenter contraceptive efficacy trial of injectable testosterone undecanoate in Chinese men. Journal of Clinical Endocrinology and Metabolism 94 1910-1915. (doi:10.1210/jc.20081846)

Handelsman DJ, Farley TM, Peregoudov A \& Waites GM 1995 Factors in nonuniform induction of azoospermia by testosterone enanthate in normal men. World Health Organization Task Force on Methods for the Regulation of Male Fertility. Fertility and Sterility 63 125-133.

Hertzog M, Milanesi F, Hazelwood L, Disanza A, Liu H, Perlade E, Malabarba MG, Pasqualato S, Maiolica A, Confalonieri S et al. 2010 Molecular basis for the dual function of Eps8 on actin dynamics: bundling and capping. PLoS Biology 8 e1000387. (doi:10.1371/journal. pbio.1000387)

Heywood R, James RW, Barcellona PS, Campana A \& Cioli V 1981 Toxicological studies on 1-substituted-indazole-3-carboxylic acids. Chemotherapy 27 91-97. (doi:10.1159/000238049)

Higgs HN 2004 There goes the neighbourhood: Eps8 joins the barbedend crowd. Nature Cell Biology 6 1147-1149. (doi:10.1038/ncb12041147)

Hild SA, Reel JR, Larner JM \& Blye RP 2001 Disruption of spermatogenesis and Sertoli cell structure and function by the indenopyridine CDB-4022 in rats. Biology of Reproduction 65 1771-1779. (doi:10.1095/biolreprod65.6.1771)

Hild SA, Marshall GR, Attardi BJ, Hess RA, Schlatt S, Simorangkir DR, Ramaswamy S, Koduri S, Reel JR \& Plant TM 2007 Development of I-CDB-4022 as a nonsteroidal male oral contraceptive: induction and recovery from severe oligospermia in the adult male cynomolgus monkey (Macaca fascicularis). Endocrinology 148 1784-1796. (doi:10. 1210/en.2006-1487)

Holmang S, Marin P, Lindstedt G \& Hedelin H 1993 Effect of long-term oral testosterone undecanoate treatment on prostate volume and serum prostate-specific antigen concentration in eugonadal middle-aged men. Prostate 23 99-106. (doi:10.1002/pros.2990230203)

Hu GX, Hu LF, Yang DZ, Li JW, Chen GR, Chen BB, Mruk DD, Bonanomi M, Silvestrini B, Cheng CY et al. 2009 Adjudin targeting rabbit germ cell adhesion as a male contraceptive: a pharmacokinetics study. Journal of Andrology 30 87-93. (doi:10.2164/jandrol.108. 004994)

Hunt PA, Susiarjo M, Rubio C \& Hassold TJ 2009 The bisphenol A experience: a primer for the analysis of environmental effects on mammalian reproduction. Biology of Reproduction 81 807-813. (doi:10.1095/biolreprod.109.077008)

Kierszenbaum AL, Rivkin E \& Tres LL 2007 Molecular biology of sperm head shaping. Society of Reproduction and Fertility Supplement $\mathbf{6 5}$ 33-43.

Koduri S, Hild SA, Pessaint L, Reel JR \& Attardi BJ 2008 Mechanism of action of I-CDB-4022, a potential nonhormonal male contraceptive, in the seminiferous epithelium of the rat testis. Endocrinology 149 1850-1860. (doi:10.1210/en.2007-1332)

Lee NP \& Cheng CY 2004a Ectoplasmic specialization, a testis-specific cell-cell actin-based adherens junction type: is this a potential target for male contraceptive development? Human Reproduction Update 10 349-369. (doi:10.1093/humupd/dmh026)

Lee NPY \& Cheng CY 2004b Adaptors, junction dynamics, and spermatogenesis. Biology of Reproduction 71 392-404. (doi:10.1095/ biolreprod.104.027268) 
Lee NPY, Mruk DD, Lee WM \& Cheng CY 2003 Is the cadherin/catenin complex a functional unit of cell-cell-actin-based adherens junctions (AJ) in the rat testis? Biology of Reproduction 68 489-508. (doi:10.1095/ biolreprod.102.005793)

Li MWM, Mruk DD, Lee WM \& Cheng CY 2009 Cytokines and junction restructuring events during spermatogenesis in the testis: an emerging concept of regulation. Cytokine and Growth Factor Reviews 20 329-338. (doi:10.1016/j.cytogfr.2009.07.007)

Lie PP, Cheng CY \& Mruk DD 2009a Coordinating cellular events during spermatogenesis: a biochemical model. Trends in Biochemical Sciences 34 366-373. (doi:10.1016/j.tibs.2009.03.005)

Lie PP, Mruk DD, Lee WM \& Cheng CY 2009b Epidermal growth factor receptor pathway substrate 8 (Eps8) is a novel regulator of cell adhesion and the blood-testis barrier integrity in the seminiferous epithelium. FASEB Journal 23 2555-2567. (doi:10.1096/fj.06-070573)

Lie PP, Chan AY, Mruk DD, Lee WM \& Cheng CY 2010 Restricted Arp3 expression in the testis prevents blood-testis barrier disruption during junction restructuring at spermatogenesis. PNAS 107 11411-11416. (doi:10.1073/pnas.1001823107)

Lie PPY, Cheng CY \& Mruk DD 2011 The biology of the desmosomelike junction: a versatile anchoring junction and signal transducer in the seminiferous epithelium. International Review of Cell and Molecular Biology 286 223-269. (doi:10.1016/B978-0-12-385859-7. 00005-7)

Liu G, Grant WM, Persky D, Latham VMJ, Singer RH \& Condeelis J 2002 Interactions of elongation factor 1 alpha with F-actin and betaactin mRNA: implications for anchoring mRNA in cell protrusions. Molecular Biology of the Cell 13 579-592. (doi:10.1091/mbc.01-030140)

Lobl TJ 1979 1-(2,4-dichlorobenzyl)-1H-indazole-3-carboxylic acid (DICA), an exfoliative antispermatogenic agent in the rat. Archives of Andrology 2 353-363. (doi:10.3109/01485017908987337)

Lobl TJ, Forbes AD, Kirton KT \& Wilks JW 1979 Characterization of the exfoliative antispermatogenic agent 1-(2,4-dichlorobenzyl)-H-indazole3-carboxylic acid in the rhesus monkey. Archives of Andrology 3 67-77. (doi:10.3109/01485017908985051)

Lui WY, Lee WM \& Cheng CY 2003 Sertoli-germ cell adherens junction dynamics in the testis are regulated by RhoB GTPase via the ROCK/LIMK signaling pathway. Biology of Reproduction 68 2189-2206. (doi:10. 1095/biolreprod.102.011379)

Martin CW, Anderson RA, Cheng L, Ho PC, van der Spuy Z, Smith KB, Glasier AF, Everington D \& Baird DT 2000 Potential impact: of hormonal male contraception: cross-cultural implications for development of novel preparations. Human Reproduction 15 637-645. (doi:10.1093/humrep/ 15.3.637)

McLaughlin EA \& Aitken RJ 2011 Is there a role for immunocontraception? Molecular and Cellular Endocrinology 335 78-88. (doi:10.1016/j.mce. 2010.04.004)

Moulana M, Lima R \& Reckelhoff JF 2011 Metabolic syndrome, androgens, and hypertension. Current Hypertension Reports 13 158-162. (doi:10. 1007/s11906-011-0184-0)

Mruk DD \& Cheng CY 2004a Cell-cell interactions at the ectoplasmic specialization in the testis. Trends in Endocrinology and Metabolism 15 439-447. (doi:10.1016/j.tem.2004.09.009)

Mruk DD \& Cheng CY 2004b Sertoli-Sertoli and Sertoli-germ cell interactions and their significance in germ cell movement in the seminiferous epithelium during spermatogenesis. Endocrine Reviews 25 747-806. (doi:10.1210/er.2003-0022)

Mruk DD \& Cheng CY 2008 Delivering non-hormonal contraceptives to men: advances and obstacles. Trends in Biotechnology 26 90-99. (doi:10.1016/j.tibtech.2007.10.009)

Mruk DD, Wong CH, Silvestrini B \& Cheng CY 2006 A male contraceptive targeting germ cell adhesion. Nature Medicine 12 1323-1328. (doi:10. 1038/nm1420)

Mruk DD, Silvestrini B \& Cheng CY 2008 Anchoring junctions as drug targets: role in contraceptive development. Pharmacological Reviews $\mathbf{6 0}$ 146-180. (doi:10.1124/pr.107.07105)

Munshi R, Kandl KA, Carr-Schmid A, Whitacre JL, Adams AE \& Kinzy TG 2001 Overexpression of translation elongation factor 1A affects the organization and function of the actin cytoskeleton in yeast. Genetics 157 1425-1436.
O'Donnell L, Nicholls PK, O'Bryan MK, McLachlan RI \& Stanton PG 2011 Spermiation: the process of sperm release. Spermatogenesis 1 14-35. (doi:10.4161/spmg/1.1.14525)

$\mathrm{O}^{\prime}$ Rand MG, Widgren EE, Sivashanmugam P, Richardson RT, Hall SH, French FS, VandeVoort CA, Ramachandra SG, Ramesh V \& Jagannadha Rao A 2004 Reversible immunocontraception in male monkeys immunized with eppin. Science 306 1189-1190. (doi:10.1126/ science.1099743)

Ozaki-Kuroda K, Nakanish H, Ohta H, Tanaka H, Kurihara H, Mueller S, Irie K, Ikeda W, Sakai T, Wimmer E et al. 2002 Nectin couples cell-cell adhesion and the actin scaffold at heterotypic testicular junctions. Current Biology 12 1145-1150. (doi:10.1016/S0960-9822 (02)00922-3)

Page ST, Amory JK \& Bremner WJ 2008 Advances in male contraception. Endocrine Reviews 29 465-493. (doi:10.1210/er.2007-0041)

Robaire B 2003 Advancing towards a male contraceptive: a novel approach from an unexpected direction. Trends in Pharmacological Sciences $\mathbf{2 4}$ 326-328. (doi:10.1016/S0165-6147(03)00141-X)

Robustelli della Guna G \& Pedrazzoli P 1991 Toxicity and clinical tolerance of lonidamine. Seminars in Oncology 18 18-22.

Russell L 1993 Morphological and functional evidence for Sertoli-germ cell relationships. In The Sertoli Cell, pp 365-390. Eds L Russell \& M Griswold. Clearwater, FL: Cache River Press.

Sharpe R 1994 Regulation of spermatogenesis. In The Physiology of Reproduction, pp 1434-1636. Eds E Knobil \& JD Neill. New York, NY: Raven.

Silvestrini B, Palazzo G \& De Gregorio M 1984 Lonidamine and related compounds. Progress in Medicinal Chemistry 21 110-135.

Siu MK \& Cheng CY 2008 Extracellular matrix and its role in spermatogenesis. Advances in Experimental Medicine and Biology 636 74-91. (doi:10.1007/978-0-387-09597-4_5)

Siu MK, Mruk DD, Lee WM \& Cheng CY 2003 Adhering junction dynamics in the testis are regulated by an interplay of beta 1-integrin and focal adhesion complex-associated proteins. Endocrinology 144 2141-2163. (doi:10.1210/en.2002-221035)

Siu MK, Wong CH, Lee WM \& Cheng CY 2005 Sertoli-germ cell anchoring junction dynamics in the testis are regulated by an interplay of lipid and protein kinases. Journal of Biological Chemistry 280 25029-25047. (doi:10.1074/jbc.M501049200)

Siu ER, Mruk DD, Porto CS \& Cheng CY 2009 Cadmium-induced testicular injury. Toxicology and Applied Pharmacology 238 240-249. (doi:10. 1016/j.taap.2009.01.028)

Sprengel R, Braun T, Nikolics K, Segaloff D \& Seeburg P 1990 The testicular receptor for follicle stimulating hormone: structure and functional expression of cloned cDNA. Molecular Endocrinology 4 525-530. (doi:10.1210/mend-4-4-525)

Tash JS, Attardi B, Hild SA, Chakrasali R, Jakkaraj SR \& Georg GI 2008a A novel potent indazole carboxylic acid derivative blocks spermatogenesis and is contraceptive in rats after a single oral dose. Biology of Reproduction 78 1127-1138. (doi:10.1095/biolreprod.106.057810)

Tash JS, Chakrasali R, Jakkaraj SR, Hughes J, Smith SK, Hornbaker K, Heckert LL, Ozturk SB, Hadden MK, Kinzy TG et al. 2008b Gamendazole, an orally active indazole carboxylic acid male contraceptive agent, targets HSP90AB1 (HSP90BETA) and EEF1A1 (eEF1A), and stimulates II1 a transcription in rat Sertoli cells. Biology of Reproduction 78 1139-1152. (doi:10.1095/biolreprod.107.062679)

Trussell J 2004 Contraceptive failure in the United States. Contraception 70 89-96. (doi:10.1016/j.contraception.2004.03.009)

Vogl AW \& Soucy LJ 1985 Arrangement and possible function of actin filament bundles in ectoplasmic specializations of ground squirrel Sertoli cells. Journal of Cell Biology 100 814-825. (doi:10.1083/jcb. 100.3.814)

Vogl AW, Pfeiffer DC, Mulhonlland D, Kimel G \& Guttman J 2000 Unique and multifunctional adhesion junctions in the testis: ectoplasmic specializations. Archives of Histology and Cytology 63 1-15. (doi:10. 1679/aohc.63.1)

Vogl A, Vaid K \& Guttman J 2008 The Sertoli cell cytoskeleton. In Molecular Mechanisms in Spermatogenesis, pp 186-211. Ed. CY Cheng. Austin, TX: Landes Bioscience/Springer Science+Business Media, LLC.

Winters SJ \& Moore JP 2007 Paracrine control of gonadotrophs. Seminars in Reproductive Medicine 25 379-387. (doi:10.1055/s-2007-984744) 
Wolgemuth DJ \& Roberts SS 2010 Regulating mitosis and meiosis in the male germ line: critical functions for cyclins. Philosophical Transactions of the Royal Society of London. Series B, Biological Sciences 365 1653-1662. (doi:10.1098/rstb.2009.0254)

Wolski KM, Perrault C, Tran-Son-Tay R \& Cameron DF 2005 Strength measurement of the Sertoli-spermatid junctional complex. Journal of Andrology 26 354-359. (doi:10.2164/jandrol.04142)

Wolski KM, Mruk DD \& Cameron DF 2006 The Sertoli-spermatid junctional complex adhesion strength is affected in vitro by adjudin. Journal of Andrology 27 790-794. (doi:10.2164/jandrol.106.000422)

Wong EWP, Mruk DD \& Cheng CY 2008a Biology and regulation of ectoplasmic specialization, an atypical adherens junction type, in the testis. Biochimica et Biophysica Acta 1778 692-708. (doi:10.1016/ j.bbamem.2007.11.006)

Wong EWP, Mruk DD \& Cheng CY $2008 b$ Delivery of contraceptives to men: lesson from other therapeutic drugs. Immunology, Endocrine \& Metabolic Agents - Medicinal Chemistry 8 91-94. (doi:10.2174/ 187152208783790660)

World Health Organization Task Force on Methods for the Regulation of Male Fertility 1990 Contraceptive efficacy of testosterone-induced azoospermia in normal men. Lancet 336 955-959. (doi:10.1016/01406736(90)92416-F)
Xia W, Mruk DD, Lee WM \& Cheng CY 2005 Cytokines and junction restructuring during spermatogenesis - a lesson to learn from the testis. Cytokine and Growth Factor Reviews 16 469-493. (doi:10.1016/j. cytogfr.2005.05.007)

Yan HH, Mruk DD, Lee WM \& Cheng CY 2007 Ectoplasmic specialization: a friend or a foe of spermatogenesis? BioEssays 29 36-48. (doi:10.1002/ bies.20513)

Yang F, Demma M, Warren V, Dharmawardhane S \& Condeelis J 1990 Identification of an actin-binding protein from Dictyostelium as elongation factor 1a. Nature 347 494-496. (doi:10.1038/347494a0)

Zhou HY, Hu GX, Hu LF, Yang DZ, Li JW, Chen GR, Silvestrini B, Cheng CY \& Ge RS 2008 Adjudin targeting dog germ cell adhesion as a male contraception. American Society of Andrology Annual Meeting, Albuquerque, NM, USA, April 12-15. Abstract.

Received 15 November 2010

First decision 27 January 2011

Accepted 9 February 2011 